\title{
MANAJEMEN PENGEMBANGAN KURIKULUM
}

\section{Gita Tri Andini}

Madrasah Tsanawiyah Al-falah Cicalengka

Jalan Kapten Sangun No.6, Tenjolaya, Kec. Cicalengka, Bandung, Jawa Barat 40141

Email: gitatriandini77@gmail.com

\section{ABSTRAK}

Pengembangan kurikulum dilakukan dengan mengacu pada standar nasional pendidikan untuk mewujudkan tujuan pendidikan nasional. Kurikulum pada semua jenjang dan jenis pendidikan dikembangkan dengan prinsip diversifikasi sesuai dengan satuan pendidikan, potensi daerah dan peserta didik. Sehingga pengembangan kurikulum yang dilaksanakan setiap satuan pendidikan menyesuaikan dengan kebutuhan madrasah. Tujuan penelitian untuk mengetahui manajemen pengembangan kurikulum. Metode penelitian deskriptif dengan menggunakan pendekatan kualitatif. Teknik pengumpulan data adalah teknik observasi, wawancara dan studi dokumentasi. Hasil penelitian ini menunjukan bahwa MTs Al-Falah Cicalengka telah melakukan pengembangan kurikulum dengan proses (1) perencanaan yang dilakukan oleh Kepala Madrasah dengan dibantu oleh Pembantu Kepala Madrasah, (2) pelaksanaan pengembangan kurikulum dilakukan melalui proses pembelajaran di dalam kelas yang mengacu kepada silabus dan RPP, (3) hasil pengembangan kurikulum berupa pengembangan kurikulum 2013 menjadi kurikulum 2013 revisi, (4) evaluasi pengembangan kurikulum oleh kepala madrasah dilaksanakan dalam jangka waktu satu semester dan evaluasi oleh guru bidang studi dilaksanakan setiap selesai proses pembelajaran.

Kata Kunci : Manajemen, Pengembangan Kurikulum, Madrasah

\section{ABSTRACK}

Curriculum development is carried out by referring to national education standards to realize national education goals. The curriculum at all levels and types of education is developed with the principle of diversification in accordance with educational units, regional potential and students. So that curriculum development carried out every educational unit adapts to the needs of the madrasah. The purpose of the study was to determine the management of curriculum development. Descriptive research method using a qualitative approach. Data collection techniques are observation, interview and documentation study techniques. The results of this study indicate that MTs AlFalah Cicalengka has developed curriculum with process (1) planning carried out by the Head of Madrasah assisted by Assistant Madrasah Principals, (2) the implementation of curriculum development is carried out through the learning process in the classroom which refers to syllabus and RPP, (3) the results of 
curriculum development in the form of 2013 curriculum development into the 2013 revised curriculum, (4) evaluation of curriculum development by the head of the madrasah is carried out within a semester and evaluation by the subject field teacher is carried out after each learning process.

Keywords: Management, Curriculum Development, Madrasah

\section{PENDAHULUAN}

Pendidikan yang diselen ggarakan di setiap satuan pendidikan, mulai dari pendidikan dasar sampai pendidikan tinggi, bahkan yang dilakukan di lembaga-lembaga nonformal dan informal seharusnya dapat menjadi landasan bagi pembentukan pribadi peserta didik dan masyarakat pada umumnya. Namun demikian, pada kenyataannya mutu pendidikan, khususnya mutu output pendidikan masih rendah jika dibanding dengan mutu ouput pendidikan di Negara lain, baik di Asia maupun di kawasan ASEAN. Rendahnya mutu pendidikan memerlukan penanganan secara menyeluruh, karena dalam kehidupan suatu bangsa, pendidikan memegang peranan yang amat penting untuk menjamin kelangsungan hidup Negara dan bangsa, juga merupakan wahana untuk meningkatkan dan mengembangkan kualitas sumber daya manusia (Mulyasa, 2014:13).

Ketika kemampuan manusia terbatas dan kebutuhan semakin tidak terbatas maka dibutuhkan pengaturan kegiatan dan pembagian kerja, sehingga manajamen di dalam dunia pendidikan sangatlah berperan penting, karena manajemen yang baik akan meningkatkan daya guna dan hasil guna semua potensi yang dimiliki, manajemen menetapkan tujuan dan usaha mewujudkan dengan memanfaatkan 6M (man, money, method, material, machines, dan market) dalam proses manajamen (Badrudin, 2013: 5).

Manajemen dapat diartikan sebagai suatu proses yang khas terdiri atas tindakan-tindakan berupa perencanaan, pengorganisasian, penggerakkan dan pengendalian yang dilaksanakan untuk menentukan serta mencapai sasaransasaran atau tujuan yang telah ditentukan melalui pemanfaatan sumber daya manusia dan sumber-sumber lainnya. Dapat juga ditegaskan manajemen adalah proses pengkoordinasian dan pengintregasian semua sumber daya untuk mencapai tujuan yang ditetapkan (Jahari, 2013: 2).

Kurikulum adalah program pendidikan yang disediakan oleh lembaga pendidikan (sekolah) bagi siswa. Berdasarkan program pendidikan tersebut siswa melakukan berbagai kegiatan belajar, sehingga mendorong perkembangan dan pertumbuhannya sesuai dengan tujuan pendidikan yang telah ditetapkan (Hamalik, 2012: 10). Kurikulum di Indonesia setelah Indonesia merdeka pada tahun 1945 telah mengalami beberapa kali perubahan, yaitu pada tahun 1947, 1952, 1964, 1968, 1975, 1984, 1994, 2004 dan tahun 2006 (Hidayat, 2013: 1).

Berbagai kebijakan perubahan kurikulum tersebut didasarkan pada hasil analisis, evaluasi, prediksi dan berbagai tantangan yang dihadapi baik internal maupun eksternal yang terus berubah. Dalam konteks ini kurikulum sebagai produk kebijakan bersifat dinamis, kontekstual dan relative. Oleh karenanya prinsip dasar dalam kebijakan kurikulum adalah change and continuity yaitu perubahan yang dilakukan secara terus menerus (Machali, 2014: 2). 
Salah satu aspek yang sangat besar pengaruhnya terhadap kurikulum adalah perkembangan dan kemajuan teknologi dan ilmu pengetahuan, yang dalam abad-abad ini ternyata berlangsung sangat pesat. Antara sekolah yang menggunakan kurikulum tertentu dengan masyarakat yang akan menerima output (lulusan) sekolah tersebut, terdapat saling ketergantungan sehingga harus saling mengisi, oleh karena itu kurikulum harus relevan dengan kebutuhan masyarakat sekarang dan di masa yang akan dating (Rosyidah, 2014: 10).

Istilah madrasah sekilas memang sama dengan sekolah umum, karena keduanya sama-sama digunakan sebagai tempat belajar mengajar ilmu pengetahuan. Akan tetapi keduanya telah memiliki sekilas perbedaan, yaitu dalam hal kurikulum dan sistemnya. Kurikulum madrasah lebih menonjolkan nilai religiusitas masyarakatnya, yakni porsi mata pelajaran Agama Islam lebih besar dari mata pelajaran umum (Faizin, 2016: 240). Salah satu upaya menjadikan madrasah unggul adalah dengan melakukan pengembangan kurikulum berbasis sekolah/madrasah. Pengembangan kurikulum bebrbasis sekolah/madrasah dapat didefinisikan sebagai upaya pengembangan kurikulum dengan menggunakan pendekatan botton up or school based Curriculum yang memberi peluang secara utuh kepada sekolah/madrasah untuk melakukan pengembangan kurikulum (Nasir, 2015: 164).

Berdasarkan hasil studi pendahuluan di Madrasah Tsanawiyah Al-Falah Cicalengka pada hari Sabtu Tanggal 09 Desember 2017 Pukul 09.00 WIB dengan Narasumber Bapak Iman Suhana, S.Ag, M.Pd.I selaku wakil kepala sekolah bidang kurikulum, mengenai pelaksanaan pendidikan di MTs AI-Falah Cicalengka berjalan dengan efektif sesuai dengan tujuan pendidikan. Kurikulum yang dipakai di MTs Al-Falah Cicalengka adalah kurikulum 2013 Revisi. Penerapan kurikulum 2013 Revisi di MTs Al-Falah Cicalengka sudah berjalan hampir 2 tahun, yakni semenjak diberlakukannya kurikulum 2013 Revisi pada tahun 2016. Meskipun ketika diberlakukannya pengembangan kurikulum dari Kurikulum 2013 menjadi Kurikulum 2013 Revisi, pihak sekolah belum mendapatkan pengarahan dan bimbingan untuk seluruh stake holders madrasah terkait adanya pengembangan pada Kurikulum 2013.

Madrasah Tsanawiyah Al-Falah Cicalengka merupakan salah satu madrasah yang banyak diminati oleh masyarakat, baik itu masyarakat di wilayah Bandung maupun diluar Bandung, karena selain terdapat sekolah umum, terdapat juga pondok pesantren. Sehingga siswa/siswi yang bersekolah di MTs al-Falah juga sekaligus menjadi santri di pondok pesantren Al-Quran AlFalah Cicalengka. Siswa yang telah menyelesaikan proses pendidikan dan pembelajaran di MTs Al-Falah Cicalengka diharapkan mampu membaca AlQur'an dengan baik dan memiliki hapalan al Qur'an (minimal 1-2 Juz untuk santri tingkat Tsnawiyah).

Berdasarkan fenomena di atas ada beberapa hal yang menarik untuk diteliti mengenai manajemen pengembangan kurikulum yang diberlakukan di MTs Al-Falah Cicalengka, sehingga dapat diidentifikasikan permasalahannya menjadi, Bagaimana Perencanaan Pengembangan Kurikulum di MTs Al-Falah Cicalengka Kabupaten Bandung ? Bagaimana Pelaksanaan Pengembangan Kurikulum di MTs Al-Falah Cicalengka Kabupaten Bandung ? Bagaimana Hasil Pengembangan Kurikulum di MTs AI-Falah Cicalengka Kabupaten Bandung ? 
dan Bagaimana Evaluasi Pengembangan Kurikulum di MTs Al-Falah Cicalengka Kabupaten Bandung ?

\section{KAJIAN TEORI}

Perencanaan merupakan hal yang harus ada ketika suatu lembaga pendidikan menginginkan adanya perubahan dan pengembangan. Perencanaan kurikulum adalah langkah awal untuk menyusun proses pengembangan kurikulum sehingga dapat mengetahui hal apa saja yang harus diperbaiki untuk melaksanakan proses pengembangan tersebut. Proses perencanaan manajemen kurikulum di sekolah harus dilaksanakan secara kolaboratif, artinya dengan mengikutsertakan personil sekolah dalam semua tahap perencanaan itu (Lubis, 2015: 15).

Pelaksanaan manajemen kurikulum merupakan bagian yang integral dari keseluruhan dari manajemen pendidikan yang diterapkan di semua jenis dan jenjang pendidikan. Bahkan tidak berlebihan jika dikatakan bahwa keberhasilan suatu lembaga pendidikan sangat ditentukan oleh manajemen kurikulumnya. Pelaksanaan kurikulum harus diarahkan agar proses pembelajaran berjalan dengan baik, dengan tolak ukur pencapaian tujuan oleh siswa. Jadi bagaimana starteginya agar tujuan pembelajaran dapat tercapat (Lubis, 2015: 14).

Ketika perencanaan dan pelaksanaan pengembangan kurikulum telah di laksanakan, maka akan terdapat hasil dari proses pengembangan kurikulum tersebut, sejauh mana perencanaan dan pelaksanaan telah tercapai dan apakah telah sesuai dengan tujuan awal. Setelah terlihat adanya hasil dari proses pengembangan kurikulum tersebut, maka diadakanlah evaluasi untuk menyempurnakan proses dari perencanaan, pelaksanaan dan hasil dari pengembangan kurikulum.

Evaluasi kurikulum merupakan tahap akhir dari pengembangan kurikulum untuk menentukan seberapa besar hasil-hasil pembelajaran tingkat ketercapaian program-program yang telah direncanakan dan hasil kurikulum itu sendiri. Evaluasi adalah proses yang berkelanjutan di mana data yang terkumpul dan dibuat pertimbangan untuk tujuan memperbaiki sistem. Evaluasi dirasa sebagai suatu proses membuat keputusan, sedangkan riset sebagai proses pengumpulan data sebagai dasar pengambilan keputusan.

\section{METODE PENELITIAN}

Dalam penelitian ini digunakan pendekatan kualitatif. Sedangkan metode yang digunakan dalam penelitian ini ialah metode penelitian deskriptif. Teknik pengumpulan data yang dilakukan ialah dengan teknik observasi, wawancara dan dokumentasi. Teknik observasi partisipasi ini dilakukan untuk mengamati letak geografis berupa denah lokasi dan kondisi lingkungan, visi, misi, strategi dan motto madrasah serta keadaan sumber daya manusia di MTs Al-Falah Cicalengka. Kemudian teknik wawancara dilakukan terlebih dahulu dengan menentukan key informant, yakni Bapak Iman Suhana, S.Ag., M.Pd.I. selaku wakil kepala sekolah bidang kurikulum. Teknik ini dilakukan untuk mengetahui informasi mengenai sejarah berdirinya MTs Al-Falah, perencanaan pengembangan kurikulum, pelaksanaan pengembangan kurikulum, hasil pengembangan kurikulum, dan evaluasi pengembangan kurikulum di MTs AlFalah Cicalengka. Sedangkan teknik dokumentasi dilakukan dengan cara 
penelusuran, dokumen dan buku yang dapat berkaitan dengan penelitian untuk mengetahui data tertulis mengenai proses pengembangan kurikulum. Teknik ini dilakukan untuk mempermudah peneliti mendapatkan informasi mengenai profil madrasah, sejarah madrasah, visi, misi, strategi dan motto madrasah, struktur organisasi dan keadaan sumber daya manusia yang terdapat di MTs AI-Falah Cicalengka. Kemudian teknik analisis yang digunakan adalah analisis data sebelum di lapangan yakni data yang ditemukan ketika telah melaksanakan studi pendahuluan, yakni analisis data mengenai kondisi objektif dan data mengenai kurikulum di MTs Al-Falah Cicalengka. Fokus analisis data disini adalah mengenai pengembangan kurikulum di MTs Al-Falah Cicalengka. Analisis data di lapangan yang terdapat 3 kegiatan yakni reduksi data, penyajian data dan verifikasi data yang dilakukan berdasarkan fokus penelitian yang diambil. Kemudian analisi data selama di lapangan yakni Key informant pada penelitian ini yaitu Wakil Kepala Sekolah Bidang Kurikulum yaitu Bapak Iman Suhana S.Ag., M.Pd.I. dan kemudian adanya Snowball Process kepada Kepala Madrasah MTs Al-Falah Cicalengka, dan kepada guru-guru mata pelajaran. Kemudian setelah dilakukannya Snowball Process, peneliti mewawancarai responden-responden tersebut melalui pertanyaan-pertanyaan deskriptif seputar pengembangan kurikulum di MTs Al-Falah Cicalengka sampai menemukan hasil yang dicari oleh peneliti berupa informasi seputar manajemen pengembangan kurikulum. Uji absah data dilakukan dengan perpanjangan pengamatan, peningkatan ketekunan, triangulasi, analisis kasus negatif, menggunakan bahan referensi dan melakukan membercheck. Uji abash data dilakukan untuk membuktikan bahwa data yang diterima merupakan data yang sebenarnya terdapat pada tempat penelitian.

\section{HASIL DAN PEMBAHASAN}

Madrasah Tsanawiyah Al-Falah Cicalengka mulai berdiri pada tahun 1982 dibawah Yayasan Asyahidiyah Al-Islamiyah. Kurikulum yang digunakan sejak berdirinya MTs Al-Falah ini adalah kurikulum 1975 dan juga menggabungkan antara kurikulum madrasah dengan kurikulum pondok pesantren. Kurikulum yang di gunakan di Madrasah Tsanawiyah Al-Falah Cicalengka pada awal berdirinya yaitu kurikulum 1975. Kondisi keadaan madrasah pada awal berdirinya masih sangat sederhana, dan minim sarana prasarana untuk proses pembelajaran. Kondisi ruangan kelas pun masih bergantian dengan Madrasah Aliyah, yakni untuk Madrasah Aliyah yaitu menggunakan ruangan kelas pada siang hari, dan untuk Madrasah Tsanawiyah menggunakan ruangan kelas pada pagi hari. Karena MTs Al-Falah merupakan madrasah swasta, maka pengembangan kurikulum di MTs Al-Falah masih sangat minim perhatian dari pemerintah. Maka ketika awal berdirinya MTs AlFalah ini, proses pelaksanaan kurikulumnya masih sangat kurang maksimal.

Pada tahun 2009 Kepala Madrasah MTs Al-Falah Cicalengka dipegang oleh Bapak Solihin, S.Ag, M.Pd.I. yang pada saat itu sedang diberlakukan Kurikulum 2006 (KTSP) pada kurikulum KTSP didiberlakukan sistem desentralisasi pendidikan. Sehingga pengelolaan kurikulum diberikan sepenuhnya kepada satuan pendidikan/sekolah. Maka dari itu penyelenggaraan pendidikan pada kurikulum 2006 ini merupakan upaya yang dilakukan oleh seluruh pihak yang terkait dalam proses pengembangan kurikulum untuk 
menentukan sendiri jenis muatan kurikulum yang dipakai sesuai dengan kebutuhan masyarakat dan berdasarkan potensi yang dimiliki oleh setiap daerah masing-masing.

Setelah diberlakukannya Kurikulum Tingkat Satuan Pendidikan (KTSP) pada tahun 2006, pada 17 Juli 2013 mulai diberlakukan Kurikulum 2013 sebagai bentuk penyempurnaan dari Kurikulum 2006 (KTSP). Pengembangan Kurikulum 2013 di Madrasah Tsanawiyah Al-Falah Cicalengka diterima baik oleh pihak madrasah, meskipun pada awalnya pihak madrasah sangat kesulitan dalam mengembangkan kurikulum 2013 tersebut. Dan pada tahun 2014 mulailah diberlakukan kurikulum 2013 di Madrasah Tsanawiyah Al-Falah Cicalengka, meskipun dalam proses pengembangan kurikulum madrasah yang berstatus swasta jarang ikut terlibat dalam proses pengembangan tersebut. Pengembangan kurikulum 2013 di Madrasah Tsanawiyah Al-Falah Cicalengka masih dalam tahap penyempurnaan, karena madrasah ini merupakan madrasah swasta, sehingga masih kurang perhatian dari pemerintah pusat dalam proses pengembangannya.

\section{Perencanaan Pengembangan Kurikulum}

Perencanaan kurikulum di MTs Al-Falah Cicalengka dimusyawarahkan oleh tim pengembang kurikulum yang terdiri dari Kepala Madrasah, PKM (Pembantu Kepala Madrasah) yakni PKM kesiswaan, PKM kurikulum, PKM humas, PKM sarana prasarana dan guru masing-masing bidang studi. Kegiatan perencanaan pengembangan kurikulum yang dilakukan oleh MTs Al-Falah Cicalengka dilaksanakan satu bulan sebelum tahun ajaran baru. Tahap perkembangan kurikulum pada proses pembelajaran mengacu kepada kurikulum Kemenag dan kemudian dirumuskan oleh MGMP (Musyawarah Guru Mata Pelajaran) sesuai dengan kebijakan yang diberikan oleh pihak madrasah.

Langkah-langkah yang dilaksanakan dalam merencanakan proses pengembangan kurikulum di MTs Al-Falah Cicalengka yaitu dengan menggunakan komponen-komponen pengembangan kurikulum yaitu :

1. Tujuan

Tujuan pengembangan kurikulum di MTs Al-Falah Cicalengka yaitu agar tercapai program pendidikan yang berkenaan dengan kemampuan siswa, untuk memudahkan pendataan guru dalam melaksanakan kurikulum 2013 dan untuk mendisiplinkan guru dalam mengikuti program pemerintah dalam menjalankan kurikulum 2013, serta tujuan pengembangan kurikulum 2013 pun secara umum mengacu kepada pendidikan nasional sesuai dengan Undang-Undang RI No. 20 Tahun 2003 Pasal 3. Sehingga pengembangan kurikulum yang dilaksanakan di MTs Al-Falah Cicalengka adalah untuk mengembangkan para peserta didik memiliki nilai-nilai yang terkandung dalam tujuan pendidikan nasional, dan peserta didik juga dituntut untuk mengembangkan nilai-nilai agama yang tertuang dalam kurikulum madrasah. Sehingga peserta didik bukan hanya cerdas dalam pengetahuan umum, namun juga cerdas pada pengetahuan agama. Dengan adanya proses pengembangan kurikulum di MTs Al-Falah Cicalengka, madrasah dapat memperbaiki kualitas yang belum sesuai dengan perkembangan-perkembangan zaman pada saat ini, sehingga dapat membantu untuk menjadikan sekolah/madrasah tersebut unggul dan diterima di masyarakat. 


\section{Isi/Materi}

Isi atau materi kurikulum yang terdapat di MTs Al-Falah Cicalengka yakni berupa silabus dari Kementrian Agama, kemudian dikembangkan oleh masingmasing guru bidang studi melalui Rencana Pelaksanaan Pembelajaran (RPP). Pembuatan RPP tersebut harus mengacu kepada Kompetensi Dasar yang terdapat dalam silabus tersebut. Dalam proses pembelajaran, setiap guru mata pelajaran memiliki buku pegangan yang disediakan oleh pemerintah, yang di dalamnya terdapat tema pembelajaran yang kemudian diuraikan melalui materimateri pembelajaran pada setiap mata pelajaran. Peserta didikpun diberikan buku siswa yang disediakan oleh pemerintah guna untuk menunjang proses pembelajaran, namun tidak seluruh siswa mendapatkan buku pegangan tersebut, dikarenakan jumlah bukunya yang terbatas sehingga ada satu atau dua siswa yang dalam satu kelas tidak mendapatkan salah satu buku pegangan siswa. Isi dari buku pegangan siswa tersebut berupa materi-materi yang akan dipelajari pada setiap mata pelajaran.

3. Metode/strategi

Penggunaan metode pembelajaran di MTs Al-Falah Cicalengka disesuaikan dengan materi pembelajaran yang akan dilaksanakan oleh setiap guru mata pelajaran, sehingga dalam proses pembelajaran tidak menggunakan satu metode saja, tetapi beberapa macam metode yang disesuaikan dengan materi pembelajaran, dan metode yang paling sering digunakan oleh guru dalam proses pembelajaran adalah metode ceramah, diskusi, dan menyimak dan demonstrasi. Tetapi pihak madrasah kali ini berusaha untuk lebih sering menggunakan media teknologi sebagai metode pembelajaran, karena teknologi dianggap berperan penting sehingga para peserta didik diharapkan mampu terbiasa dengan penggunaan media teknologi dengan benar. Adapun kekurangan dari penggunaan media teknologi ini adalah masih minimnya media yang terdapat di MTs Al-Falah Cicalengka. Penggunaan lab komputer yang masih harus bergantian dengan kelas lain, dan penggunaan infokus yang sama halnya dengan lab komputer, bahwasanya untuk menggunakan media tersebut harus bergantian ataupun harus memiliki jadwal terlebih dahulu.

4. Evaluasi

Evaluasi dalam proses pembelajaran dilakukan ketika proses pembelajaran selesai, peserta didik diberikan sebuah pertanyaan baik berbentuk soal maupun berupa pertanyaan, hal tersebut dilakukan agar peserta didik dalam proses pelaksanaan pembelajaran dapat menyimak dengan baik materi yang disampaikan oleh guru, dan dapat memahami materi yang dipelajari pada saat itu. Sehingga apabila dalam proses pelaksanaan pembelajaran peserta didik tidak dapat memahami materi tersebut, guru akan memberikan penjelasan kembali terkait materi tersebut kepada seluruh siswa, meskipun hanya satu atau dua anak yang tidak memahaminya. Hal tersebut dilakukan agar peserta didik yang tidak memahami materi tersebut dan tidak merasa dianggap kurang oleh teman yang lainnya.

\section{Pelaksanaan Pengembangan Kurikulum}

Proses pelaksanaan pengembangan kurikulum di MTs Al-Falah Cicalengka masih dalam proses pengembangan, karena tidak ada keterlibatan dari pihak madrasah dalam proses pengembangan kurikulum di Kementrian Agama menjadi salah satu faktor yang berdampak kepada ketertinggalan pihak 
madrasah dalam mengembangkan kurikulumnya, sehingga pihak madrasah harus berusaha mencari informasi-informasi terkait pengembangan kurikulum yang dipakai pada saat ini. Adapun proses pelaksanaan yang dilakukan di MTs Al-Falah Cicalengka yaitu :

1. Pelaksanaan Kurikulum Tingkat Sekolah

Pelaksanaan pengembangan kurikulum tingkat sekolah dilakukan oleh Kepala Madrasah selaku administrator dan supervisor madrasah yang bertugas untuk memberi arahan kepada seluruh stakeholders madrasah terutama guru untuk dapat menjalankan tugasnya dengan baik sehingga dapat mengembangkan kurikulum madrasah menjadi lebih baik lagi. Pelaksanaan kurikulum di MTs Al-Falah Cicalengka masih berjalan secara bertahap mengikuti pengembangan kurikulum kemenag, dikarenakan kurangnya perhatian dari pemerintah kepada sekolah swasta menjadikan MTs Al-Falah kurang mengikuti perkembangan kurikulum yang berlaku. Dan pada saat diberlakukannya Kurikulum 2013 Revisi, pihak madrasah masih kurang mendapat pengarahan terhadap guru-guru, sehingga pihak madrasah harus mencari informasi terkait pengembangan kurikulum yang diberlakukan pada saat ini. Terdapat pula beberapa guru yang masih belum mengetahui kurikulum yang diberlakukan oleh pihak madrasah menjadikan perkembangan kurikulum di MTs Al-Falah belum berjalan dengan sepenuhnya. Penggunaan alokasi waktu yang masih menggunakan kurikulum 2006 (KTSP) merupakan salah satu bentuk keterlambatan pihak madrasah dalam mengembangkan kurikulum madrasah.

2. Pelaksanaan Kurikulum Tingkat Kelas

Pelaksanaan pengembangan kurikulum tingkat kelas dilaksanakan oleh guru. Dalam pelaksanaan pembelajaran seorang guru ketika masuk ruangan kelas mengucapkan salam terlebih dahulu, kemudian berdoa bersama, mengabsen peserta didik dan kemudian memberikan materi pembelajaran. Guru dalam melaksanakan kegiatan pembelajarannya harus sekreatif mungkin agar siswa tidak merasa bosan dan jenuh dengan proses pembelajaran tersebut. Kurikulum yang dipakai pada saat ini di MTs Al-Falah Cicalengka adalah Kurikulum 2013 Revisi, tetapi dalam jadwal pembelajaran di MTs AlFalah Cicalengka menggunakan jadwal KTSP. Sehingga pada hari sabtu yang harusnya sekolah diliburkan, MTs Al-Falah Cicalengka tidak meliburkan kegiatan pembelajaran. Dikarenakan alokasi waktu yang harus disesuaikan dengan kegiatan pondok pesantren, sehingga pihak madrasah memutuskan untuk mengurangi alokasi waktu pembelajaran yang nantinya akan digantikan pada hari sabtu. Melihat hal tersebut, pelaksanaan pengembangan Kurikulum 2013 Revisi di MTs Al-Falah Cicalengka belum sesuai dengan aturan pemerintah. Tetapi meskipun begitu, pihak madrasah diberi kewenangan untuk mengatur segala bentuk kegiatan yang berhubungan dengan proses pembelajaran.

\section{Hasil Pengembangan Kurikulum}

Kurikulum yang digunakan di MTs Al-Falah Cicalengka adalah Kurikulum 2013 Revisi sebagai bentuk penyempurnaan dari Kurikulum 2013 yang lalu. Tidak terdapat perbedaan dari proses pembelajaran menggunakan K13 Revisi, karena setiap setiap guru berpendapat bahwasanya proses pelaksanaan pengajaran itu sama saja, yang membedakan hanyalah metode-metode yang 
cukup bervariasi, penggunaan media teknologi yang sekarang diharuskan kepada setiap peserta didik. Sehingga peserta didik dituntut untuk mengerti penggunaan media teknologi guna untuk menunjang proses pembelajaran. Meskipun dalam proses pembelajaran di MTs Al-Falah Cicalengka penggunaan media teknologi tersebut masih dibatasi. Perbedaan lain yang terdapat di K13 Revisi hanyalah istilah-istilah yang digunakan, kemudian aplikasi penilaian siswa yang sekarang menjadi lebih mudah. Apabila pada Kurikulum 2013 lalu, penilaian siswa harus dipisah antara aspek kognitif, afektif dan psikomotorik.

Dalam pelaksanaan pengembangan kurikulum di MTs Al-Falah Cicalengka masih dalam proses bertahap, karena kurangnya pembinaan terhadap para guru di MTs Al-Falah Cicalengka terkait pengembangan kurikulum 2013 Revisi menjadikan guru-guru hanya bisa memahami dari berbagai informasi saja. Maka dari itu pengembangan kurikulum di MTs AlFalah Cicalengka belum berjalan sepenuhnya, karena masih dalam proses pengembangan. Guru-guru pun sebagian ada yang tidak mengetahui apakah kurikulum yang diberlakukan adalah Kurikulum 2013 atau Kurikulum 2013 revisi. Kemudian jadwal pembelajaran yang diberlakukan oleh pihak madrasah yaitu masih menggunakan jadwal pembelajaran KTSP, yakni hari sabtu tidak diliburkan, hal tersebut dilakukan guna untuk mengganti jam-jam pembelajaran yang pada hari biasa dikurangi alokasi waktunya. Namun, meskipun MTs AIFalah masih menggunakan jadwal pembelajaran KTSP tetapi Kurikulum yang dipakai adalah Kurikulum 2013 Revisi.

Selain itu, mata pelajaran yang berlaku di MTs Al-Falah Cicalengka terdapat perbedaan dengan teori, pada kurikulum 2013 untuk mata pelajaran Teknologi, Informasi dan Komunikasi sudah dihapuskan karena TIK diharuskan untuk menjadi sebuah media pembelajaran. Setiap mata pelajaran diharuskan untuk sering menggunakan media teknologi, guna untuk membantu peserta didik mencari informasi dengan mudah, belajar memahami mengenai penggunaan media teknologi dengan benar agar membantu peserta didik dalam pelaksanaan UNBK yang mengharuskan setiap peserta didik memakai media teknologi berupa komputer.

Sedangkan di MTs Al-Falah Cicalengka ini, mata pelajaran Teknologi, Informasi dan Komunikasi masih diberlakukan sebagai pengganti mata pelajaran prakarya. Yang mana prakarya di MTs Al-Falah Cicalengka adalah mata pelajaran TIK dan Bahasa Daerah (Bahasa Sunda). Mata pelajaran prakarya di MTs Al-Falah Cicalengka sempat diberlakukan pada awal penerapan Kurikulum 2013. Namun mata pelajaran prakarya tersebut hanya bertahan selama satu semester saja. Hal tersebut dikarenakan kurangnya ketersediaan dan kesiapan pihak madrasah memberlakukan mata pelajaran prakarya, karena mata pelajaran prakarya mengharuskan peserta didik mencoba mengolah sesuatu sampai dengan memasarkannya. Tetapi pihak madrasah belum sampai kepada tahapan tersebut maka mata pelajaran prakarya yang seharusnya berupa keterampilan peserta didik mengolah sesuatu sampai dengan memasarkan diganti dengan mata pelajaran TIK, yang seharusnya sudah dihapuskan untuk diganti sebagai media pembelajaran.

\section{Evaluasi Pengembangan Kurikulum}

Madrasah Al-Falah Cicalengka dalam melakukan proses evaluasi belum melaksanakan kegaiatan evaluasi pengembangan kurikulum. Tetapi pihak 
madrasah hanya melakukan kegiatan evaluasi hasil pembelajaran saja. Maka dari itu, masih banyak PR bagi pihak madrasah dalam melakukan evaluasi pengembangan kurikulum. Adapun proses evaluasi yang dilakukan di MTs AlFalah Cicalengka yaitu :

1. Evaluasi Hasil Pembelajaran

Evaluasi hasil pembelajaran ini dilakukan oleh setiap guru mata pelajaran, yang dilakukan ketika proses pelaksanaan pembelajaran telah selesai. Karena pada Kurikulum 2013 Revisi, sistem penilaian siswa tidak hanya dilakukan pada akhir semester saja tetapi juga dilakukan setelah selesainya proses pembelajaran. Evaluasi hasil pembelajaran di MTs Al-Falah sudah sesuai dengan teori, yang mana terdapat evaluasi formatif dan evaluasi sumatif. Evaluasi formatif yang dilaksanakan di MTs Al-Falah Cicalengka merupakan evaluasi harian yang dilakukan untuk menilai proses pembelajaran pada saat proses pembelajaran telah selesai, seorang guru dianjurkan untuk mengevaluasi hasil pembelajaran peserta didik setelah selesai pembelajaran, baik berupa pemberian butir-butir soal maupun berupa pertanyaan, guna untuk mengetahui apakah anak tersebut dapat memahami materi pembelajaran pada saat itu atau tidak. Kemudian evaluasi sumatif yang dilaksanakan di MTs AlFalah Cicalengka dilakukan pada akhir semester berupa penilaian akhir semester atau dalam istilah Kurikulum 2013 yang lalu adalah ujian akhir semester. Apabila siswa tidak mendapatkan nilai sesuai dengan KKM yang telah ditentukan, maka siswa diberikan remedial secara berulang sampai siswa tersebut dapat memenuhi batas $\mathrm{KKM}$ yang telah ditentukan oleh masingmasing guru mata pelajaran. Maka dari pernyataan diatas, evaluasi yang dilakukan di MTs AI-Falah Cicalengka telah sesuai dengan teori. Yakni terdapat evaluasi formatif dan evaluasi sumatif.

Sesuai dengan kebijakan kurikulum baru yang berlaku di MTs AI-Falah Cicalengka yakni Kurikulum 2013 Revisi, yang mana pada sistem pembelajarannya menggunakan pendekatan scientific dan dalam proses penilaiannya menggunakan penilaian autentik. MTs Al-Falah Cicalengka sudah menerapkan pembelajaran scientific dan penilaian autentik. Pendekatan scientific mengacu kepada proses pembelajaran 5M yakni (Mengamati, Menanya, Mencoba, Menalar dan Mengkomunikasikan). Sedangkan penilaian autentik adalah penilaian kinerja, portofolio dan penilaian proyek, sehingga dalam pelaporan hasil penilaian peserta didik dilakukan secara objektif, akuntabel dan informatif. Karena pada dasarnya penilaian autentik mencakup tiga ranah hasil belajar yakni ranah sikap, keterampilan dan pengetahuan. Sehingga setiap guru dapat mengetahui melalui aspek sikap, keterampilan dan pengetahuan apa saja yang sudah atau belum dimiliki oleh setiap peserta didik, dari situlah seorang guru dapat dengan mudah melakukan evaluasi dengan menggabungkan 3 aspek tersebut untuk membantu perkembangan peserta didik kedepannya.

2. Evaluasi Pelaksanaan Pembelajaran

Evaluasi yang dilaksanakan di MTs Al-Falah Cicalengka dilakukan setiap semester oleh Kepala Madrasah, tugas kepala madrasah dalam proses evaluasi yakni mengevaluasi perangkat-perangkat yang belum sesuai dengan proses pembelajaran, serta kegiatan supervisi yang dilakukan oleh kepala madrasah untuk mengechek kegiatan proses pembelajaran di dalam kelas. 
Evaluasi juga dilakukan oleh pihak kemenag untuk mengukur penilaian kinerja guru (PKG) di MTs Al-Falah Cicalengka. Maka pelaksanaan evaluasi di MTs AlFalah Cicalengka sudah sesuai dengan teori, yakni mengevaluasi seluruh pelaksanaan pembelajaran.

Namun untuk kegiatan evaluasi yang dilakukan oleh pihak Kementrian Agama itu sendiri sangat jarang dilakukan, meskipun setiap satu semester dilakukan kegiatan monitoring tetapi sifatnya hanya sekedar monitoring kegiatan evaluasi madrasah, dan untuk kegiatan PKG di MTs Al-Falah Cicalengka pada tahun 2014 pihak madrasah pernah sempat meminta untuk diadakannya PKG oleh Kementrian Agama. Hal tersebut dirasakan oleh pihak madrasah karena kurangnya perhatian dari pemerintah terhadap madrasah yang berstatuskan swasta.

\section{SIMPULAN}

Pelaksanaan pengembangan kurikulum di MTs Al-Falah Cicalengka dilakukan oleh kepala madrasah selaku administrator yang bertugas memberikan pembinaan terhadap seluruh stakeholders madrasah terutama kepada guru terkait perangkat pembelajaran. Hasil pengembangan kurikulum di MTs Al-Falah Cicalengka ini berupa pengembangan Kurikulum 2013 menjadi Kurikulum 2013 Revisi. Dalam pengembangan kurikulum ini, pihak madrasah dapat mengembangkan Kurikulum 2013 Revisi secara bertahap dengan baik.

\section{REFERENSI}

Ammminah, Murniati Ar, dan Nasir Usman, 2015.“Implementasi Manajemen Berbaasis Sekolah dalam Meningkatkan Mutu Pendidikan Pada MTsN Kota Lhokeumawe", jurnal administrasi pendidikan, pascasarjana universitas syiah kuala Vol 03, No. 02.

Badrudin. (2013). Dasar-dasar Manejemen. Bandung: Alfabeta.

Faizin, Hamam dkk. (2016). Ensiklopedia Madrasah. Jakarta: Direktorat Pendidikan Madrasah.

Hidayat, Sholeh. (2013). Pengembangan Kurikulum Baru. Bandung: Remaja Rosdakarya.

Jahari, Jaja. (2013). Manajemen Madrasah: Teori, Strategi dan Implementasi. Bandung: Alfabeta.

Lubis, Yusuf Amri. Pelaksanaan Manajemen Kurikulum pada SMA Negeri 1 Buengcala Kabupaten Aceh Besar. Jurnal Administrasi Pendidikan. Vol. 3, Nomor 1, Febuari 2015.

Machali, Imam. Kebijakan Perubahan Kurikulum 2013 dalam Menyongsong Indonesia Emas Tahun 2045. Jurnal Pendidikan Islam. Vol. 4, Nomor 1, Juni 2014.

Mulyasa, E. (2014). Pengembangan dan Implementasi Kurikulum 2013. Bandung: Rosdakarya.

Oemar Hamalik. (2012). Manajemen Pengembangan Kurikulum.. Bandung: Remaja Rosdakarya,

Rosyidah, Ida. (2014). Pengelolaan Kelas yang Bernuansa Aktif dan Inovatif. Bandung: Ice Consultan. 